\title{
Threonine appears to be essential for proliferation of human as well as mouse embryonic stem cells
}

\author{
Lon J. Van Winkle ${ }^{1 *}$, Vasil Galat ${ }^{2}$ and Philip M. lannaccone ${ }^{3}$ \\ ' Department of Biochemistry, Midwestern University, Downers Grove, IL, USA \\ 2 Developmental Biology Program, Department of Pathology, Lurie Children's Research Center, Feinberg School of Medicine, Northwestern University, Chicago, IL, \\ USA \\ ${ }^{3}$ Developmental Biology Program, Department of Pediatrics, Lurie Children's Research Center, Feinberg School of Medicine, Northwestern University, Chicago, IL, \\ USA \\ ${ }^{*}$ Correspondence: Ivanwi@midwestern.edu
}

Edited by:

Masatake Osawa, Gifu University, Japan

Reviewed by:

Amy Ralston, University of California Santa Cruz, USA

Masatake Osawa, Gifu University, Japan

Keywords: threonine, embryonic stem cells, cell proliferation, humans, amino acid transport systems

\section{A commentary on}

Dependence of mouse embryonic stem cells on threonine catabolism

by Wang, J., Alexander, P., Wu, L., Hammer,

R., Cleaver, O., and McKnight, S. L. (2009).

Science 325, 435-439. doi: 10.1126/sci-

ence. 1173288

Regulation of L-threonine dehydrogenase in somatic cell reprograming

by Han, C., Gu, H., Wang, J., Lu, W., Mei, Y., and Wu, M. (2013). Stem Cells 31, 953965. doi: 10.1002/stem.1335

Threonine metabolism and embryonic stem cell self-renewal

by Chen, G., and Wang, J. (2014). Curr. Opin. Clin. Nutr. Metab. Care 17, 80-85. doi: 10.1097/MCO.0000000000000007

\section{INTRODUCTION}

Mouse embryonic stem (mES) cell proliferation depends exclusively on the nutritionally essential amino acid, Lthreonine, in the medium. Other essential and non-essential amino acids need not be added to the medium for mES cell proliferation. Furthermore, the threonine analog, 3-hydroxynorvaline (3-HNV), selectively inhibits mES cell proliferation (Wang et al., 2009). HeLa, MEF and 3T3 cell growth all are not affected by 3 -HNV. Selective inhibition of ES cell proliferation by $3-\mathrm{HNV}$ is expected to have teratogenic and embryotoxic effects on development, and these effects have been observed in chicken and mouse embryos (Louw et al., 2005).

It has been proposed that rapid catabolism via threonine dehydrogenase (TDH) accounts for how threonine supplementation is needed to support mES cell proliferation and that TDH is the site of 3-HNV inhibition of mES cell proliferation (Wang et al., 2009; Han et al., 2013; Chen and Wang, 2014). In support of this possibility, TDH induction enhances reprogramming of mouse somatic cells into induced pluripotent stem (iPS) cells, and $3-\mathrm{HNV}$ inhibits this induction (Han et al., 2013). The concentrations of threonine or 3-HNV needed for mES cell proliferation or its inhibition are, however, over an order of magnitude lower than the apparent $K_{\mathrm{m}}$ or $K_{\mathrm{i}}$ values for interaction of threonine or 3-HNV with TDH (Wang et al., 2009). Hence, another mechanism may account for the influences of threonine and 3-HNV on mES cell proliferation. To test this hypothesis, we determined whether $3-\mathrm{HNV}$ inhibits human embryonic stem (hES) cell proliferation. Humans produce truncated and apparently inactive $\mathrm{TDH}$ proteins that cannot make appropriate contact with 3$\mathrm{HNV}$, threonine or $\mathrm{NAD}^{+}$, the cofactor needed for TDH activity (Edgar, 2002).

\section{MATERIALS AND METHODS}

hES cells (H9 cell line, WA09) were maintained in complete Stem-Pro medium, DMEM/F12, supplemented with GlutaMax, ${ }^{\mathrm{TM}}$ Stem Pro ${ }^{\circledR}$ Supplement, Bovine Serum Albumin, FGF, and
$2, \beta$-Mercapthneol; the medium was changed daily. Human ES cells were cultured for 3 days prior to removal of medium and addition of experimental culture media. ES cells were cultured without mouse feeder cells. The diameters of all colonies were measured daily for 3 days using an inverted microscope. Each treatment group included at least six colonies in each of three independent experiments (total of at least 18 colonies in each group). The mean colony diameters of each of the four groups indicated in Figure 1 were compared statistically using analysis of variance (except the $3-\mathrm{HNV}$ treatment group on day 3 ).

\section{RESULTS AND DISCUSSION}

The diameters of all colonies were measured daily for 3 days using an inverted microscope (except the 3-HNV treatment group on day 3). Four mM 3-HNV inhibited growth of hES cell colonies over the first 2 days of treatment $(p<$ $0.0001)$. Moreover, hES cell colonies lost integrity and dissociated after 3 days of treatment with $4.0 \mathrm{mM} 3-\mathrm{HNV}$. All such colonies appeared to be dead. Four $\mathrm{mM}$ L-threonine largely rescued hES cells from 3-HNV inhibition $(p<0.0001)$ and apparent toxicity. This threonine rescue from 3-HNV included elongation and apparent differentiation of a greater proportion of rescued hES cells relative to control hES cells, so the rescue was likely incomplete (e.g., Figure 1). Nevertheless, TDH cannot be the site of 3-HNV action in hES cells nor can it account for the 

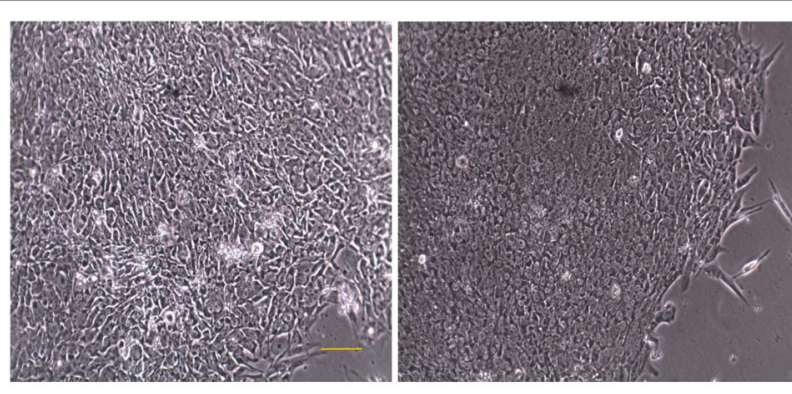

Control

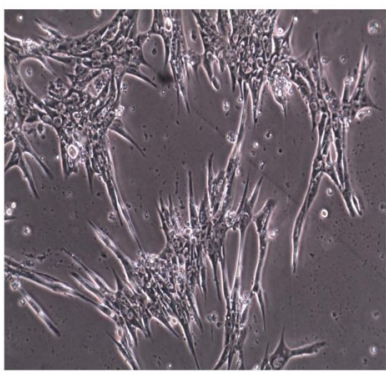

3-HNV
L-Threonine

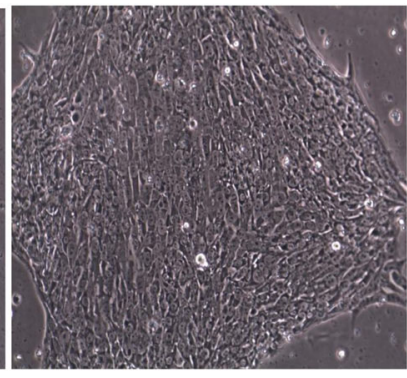

Both 3-HNV and L-Threonine

FIGURE 1 | hES cell and colony morphology after 2 days of culture in complete Stem-Pro medium (control) or this medium containing $4.0 \mathrm{mM}$ L-threonine, 3-HNV or both 3-HNV and L-threonine. Threonine $(4.0 \mathrm{mM})$ rescued hES cells from $4.0 \mathrm{mM} 3-\mathrm{HNV}$. (Scale bar $=50 \mathrm{um}$ )

ability of threonine to rescue hES cells from 3-HNV. These observations open the question whether $\mathrm{TDH}$ is the only site of action of 3-HNV and threonine in mES cells. In this regard, threonine regulates the G1/S phase transition in mES cells in part through interaction with an amino acid transport system in the plasma membrane of the cells (Ryu and Han, 2011).

\section{AUTHOR CONTRIBUTIONS}

Lon J. Van Winkle conceived and designed the study; collected and assembled the data with the help of Vasil Galat analyzed and interpreted the data with the help of Philip

M. Iannaccone; and wrote the manuscript with the help of Philip M. Iannaccone and Vasil Galat; Vasil Galat: provided the stem cells and performed the experiments; Philip M. Iannaccone: provided financial and administrative support. All authors approved the manuscript in its final form and agree to be accountable for it.

\section{ACKNOWLEDGMENTS}

Funded in part by Eisenberg Foundation for Charities (Philip M. Iannaccone) and the Illinois Institute for Regenerative Medicine (Philip M. Iannaccone, Vasil Galat).

\section{REFERENCES}

Chen, G., and Wang, J. (2014). Threonine metabolism and embryonic stem cell self-renewal. Curr. Opin. Clin. Nutr. Metab. Care 17, 80-85. doi: 10.1097/MCO.0000000000000007

Edgar, A. J. (2002). The human L-threonine 3dehydrogenase gene is an expressed pseudogene. BMC Genet. 3:18. doi: 10.1186/1471-2156-3-18

Han, C., Gu, H., Wang, J., Lu, W., Mei, Y., and Wu, M. (2013). Regulation of L-threonine dehydrogenase in somatic cell reprograming. Stem Cells 31 , 953-965. doi: 10.1002/stem.1335

Louw, R., Potgieter, H. C., and Vorster, W. (2005) Teratogenicity of 3-hydroxynorvaline in chicken and mouse embryos. Amino Acids 29, 207-212. doi: 10.1007/s00726-005-0233-6

Ryu, J. M., and Han, H. J. (2011). L-Threonine regulates $\mathrm{G}_{1} / \mathrm{S}$ phase transition of mouse embryonic stem cells via PI3K/Akt, MAPKs, and mTORC pathways. J. Biol. Chem. 286, 23667-23678. doi: 10.1074/jbc.M110.216283

Wang, J., Alexander, P., Wu, L., Hammer, R., Cleaver, O., and McKnight, S. L. (2009). Dependence of mouse embryonic stem cells on threonine catabolism. Science 325, 435-439. doi: 10.1126/science. 1173288

Conflict of Interest Statement: The authors declare that the research was conducted in the absence of any commercial or financial relationships that could be construed as a potential conflict of interest.

Received: 26 February 2014; accepted: 28 April 2014; published online: 20 May 2014.

Citation: Van Winkle LJ, Galat V and Iannaccone PM (2014) Threonine appears to be essential for proliferation of human as well as mouse embryonic stem cells. Front. Cell Dev. Biol. 2:18. doi: 10.3389/fcell. 2014.00018

This article was submitted to Stem Cell Research, a section of the journal Frontiers in Cell and Developmental Biology.

Copyright (c) 2014 Van Winkle, Galat and Iannaccone. This is an open-access article distributed under the terms of the Creative Commons Attribution License (CC BY). The use, distribution or reproduction in other forums is permitted, provided the original author(s) or licensor are credited and that the original publication in this journal is cited, in accordance with accepted academic practice. No use, distribution or reproduction is permitted which does not comply with these terms. 